\title{
REVIEW
}

\section{Thrombin in inflammation and healing: relevance to rheumatoid arthritis}

\author{
Ruth Morris, Paul G Winyard, David R Blake, Christopher J Morris
}

Thrombin is classically recognised as factor IIa of the coagulation cascade, where it catalyses the conversion of fibrinogen into fibrin and so aids in the formation of a blood clot. Active thrombin is generated from prothrombin at the cell surface of platelets, lymphocytes, monocytes, neutrophils and endothelial cells. ${ }^{1}$ It belongs to the serine protease enzyme group, members of which share a common catalytic mechanism and also the triad of amino acids at their active site (aspartate-serine-histidine) from which their name derives. Thrombin has several forms, the largest and most active of which is $39 \mathrm{kD} \alpha$-thrombin. It is able to catalyse the cleavage of a wide range of proteins including itself.

Recently it has been found that thrombin causes a number of pro-inflammatory and mitogenic effects, many of which appear to take place after thrombin cleavage of a G-protein coupled transmembrane receptor. These in vitro observations suggest that thrombin may be important in the healing process, acting as a mediator of inflammation and initiating repair through the stimulation of cell growth. It has also been linked with the development of vascular disease, notably atherosclerosis. ${ }^{2}$ However, the multiple actions of thrombin implicate this enzyme in the pathogenesis of any disorder where there is sustained vascular injury and cellular infiltration.

In particular thrombin may be important during the progression of rheumatoid arthritis (RA), a chronic inflammatory disease marked by increased vascular permeability, synovial proliferation, and an abnormal angiogenic response. Extravascular coagulation is also seen in RA, with fibrin deposition being a well documented feature of inflamed synovial tissue. Advances in immunohistochemical techniques have made it possible to demonstrate the existence of intact coagulation pathways within the rheumatoid synovium. ${ }^{34}$ This review describes current knowledge about how thrombin works to promote successful healing, and outlines the pathological relevance of prolonged and inappropriate thrombin activity in RA.

\section{Generation and regulation of thrombin}

THE PROTHROMBINASE COMPLEX

Thrombin is generated through the action of Factor $\mathrm{Xa}$ and Factor $\mathrm{Va}$, which form a complex together with phospholipids in the membranes of platelets, endothelial cells, lymphocytes, neutrophils, and monocytes. ${ }^{1}$ This 'prothrombinase' complex then catalyses cleavage of prothrombin, with the resulting loss of a $32 \mathrm{kD}$ fragment and formation of active thrombin.

As with other stages in the coagulation cascade, thrombin generation is controlled by several feedback loops which exert both positive and negative influences on the amount of thrombin formed. For example thrombin binds to thrombomodulin, a glycoprotein found in the endothelial cell membrane and the membranes of other cell types including synovial macrophages. ${ }^{5} 6$ This binding alters the thrombin molecule so that it no longer catalyses fibrinogen cleavage, but instead becomes an efficient activator of protein $\mathrm{C}$, a serine protease which inactivates Factor $\mathrm{Va} .{ }^{7}$ In this way thrombin is able to curtail its own generation (fig 1). Raised levels of thrombomodulin have recently been reported in RA synovial fluid, ${ }^{8}$ suggesting that thrombomodulin may be important in the control of thrombin during inflammatory joint disease.

ENDOGENOUS THROMBIN INHIBITORS

Uncontrolled thrombin action is prevented by members of the serine protease inhibitor (serpin) superfamily, ${ }^{9}$ which embraces a large number of regulatory plasma proteins such as plasminogen activator inhibitor-1 (PAI-1) and $\alpha_{2}$-antiplasmin. Serpins display sequence homology and share common structural features, forming stable 1:1 complexes with serine protease enzymes. They possess a reactive centre as part of an external polypeptide loop, and within this reactive centre is a bond that can be cleaved by the target enzyme. Particular serpins tend to be more efficient as inhibitors of certain serine proteases, but none are entirely specific.

Antithrombin III (AT-III) is the main circulating inhibitor of thrombin, although other serpins may also contribute. It complexes with thrombin through its reactive arginineserine bond, ${ }^{10}{ }^{11}$ and can also inhibit Factors IXa, Xa, XIa and XIIa. However, thrombin appears able to bind to the subendothelial extracellular matrix without loss of function and, once bound, is protected from inhibition by plasma AT-III. ${ }^{12}$ It is therefore not surprising to find a second serpin, protease nexin-1 (PN-1), that directly controls thrombin action at the cell surface. PN-1 is secreted by many cell types in vitro including human and mouse fibroblasts ${ }^{13}{ }^{14}$ and bovine 

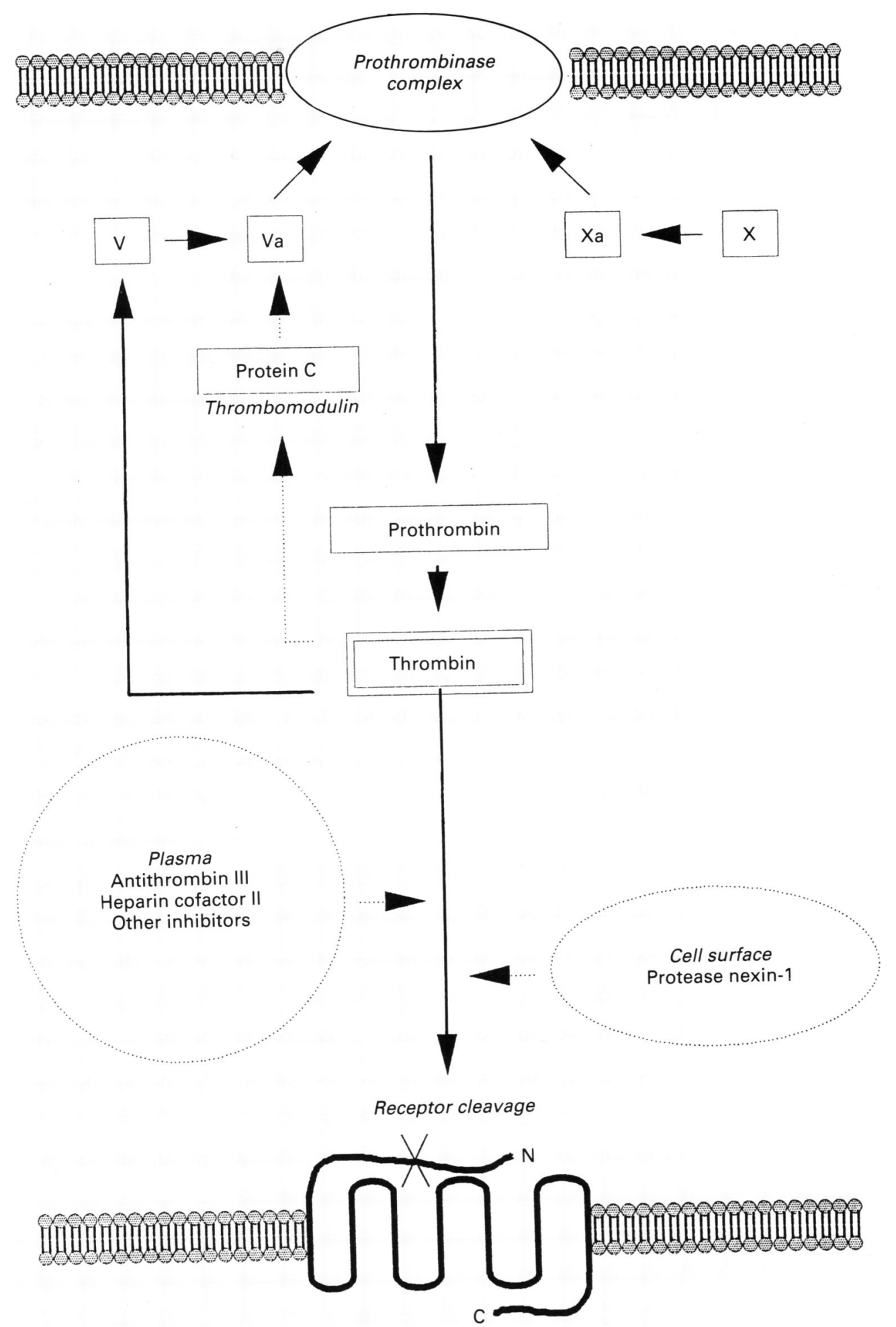

Thrombin receptor

Figure 1 Simplified diagram showing generation, action, and inhibition of thrombin. Solid arrows = activation mechanisms, dotted arrows = inhibitory mechanisms.

aortic endothelial cells, ${ }^{15}$ where it acts primarily as a thrombin inhibitor after cell surface binding. ${ }^{16}$ Thrombin inhibition by a further plasma serpin, heparin cofactor II (HC-II), has been demonstrated. ${ }^{17} \mathrm{HC}-\mathrm{II}$ differs from ATIII and PN-1 in that its reactive bond contains leucine in preference to the usual arginine residue. ${ }^{18}$ The physiological significance of this inhibitor is not well understood.

The rates of thrombin-inhibition by AT-III, PN-1 and HC-II are greatly increased in the presence of glycosaminoglycans such as heparin and heparan sulphate, ${ }^{19-22}$ which are found in mast cells and on endothelial cell surfaces respectively. In addition, PAI-1 also becomes an efficient thrombin inhibitor in the presence of heparin. ${ }^{23}$ The involvement of glycosaminoglycans in coagulation has recently been reviewed, ${ }^{24}$ and heparin itself is used clinically as an anticoagulant because of its ability to accelerate the inhibition of thrombin by antithrombin III. 
Inactivation of serpins in inflamed tissues Serpins are susceptible to inactivation during the inflammatory process, owing to the exposed location of their reactive centre on the outside of the molecule. Reactive oxygen species from neutrophils readily oxidise a critical methionine residue, present in the reactive centre of several serpins, for example, $\alpha_{1}$-antitrypsin $\left(\alpha_{1}-\mathrm{AT} ;{ }^{25}\right)$. Moreover the presence of inflammatory mediators such as interleukin-1 (IL-1) stimulates the release of various cell-derived protease enzymes. ${ }^{26}$ Neutrophils produce elastase, a serine protease, and connective tissue cells secrete metalloproteinases including collagenase and the stromelysins. These enzymes degrade joint tissues. They can also inactivate serpins by proteolysis within the exposed loop region, and so may disturb the delicate balance between thrombin and its inhibitors.

Such an event has already been demonstrated for neutrophil elastase, whose associated serpin, $\alpha_{1}-\mathrm{AT}$, can be cleaved by stromelysin. ${ }^{27} 28$ The proportion of cleaved $\alpha_{1}-\mathrm{AT}$ in RA synovial fluid is higher than in osteoarthritic synovial fluid or normal serum, ${ }^{29}$ and consequently RA synovial fluid has a reduced capacity for elastase inhibition. ${ }^{30}$ Elastase itself will cleave both AT-III and $\mathrm{PN}-1$ in vitro, and after cleavage these serpins are no longer effective as thrombin inhibitors. ${ }^{31-33}$

\section{Thrombin in inflammation and healing} THROMBIN AS A MEDIATOR OF INFLAMMATION As might be expected of a coagulative enzyme, thrombin acts directly to cause platelet aggregation $^{34}$ and potentiate coagulation. As well as activating Factor $\mathrm{V}^{35}$ and stimulating release of factor VIII from the endothelium, ${ }^{36}$ it increases the production of tissue plasminogen activator ${ }^{37}$ and PAI- $1^{38}$ by endothelial cells.

Thrombin also contributes to the inflammatory process by upregulating arachidonic acid synthesis. This in turn leads to the release by endothelial cells ${ }^{39}$ of prostacyclin $\left(\mathrm{PGI}_{2}\right)$, a powerful vasodilator and, paradoxically, an inhibitor of platelet aggregation. In addition, thrombin enhances production of platelet activating factor, ${ }^{40}$ which is a potent mediator of inflammatory changes including vasodilatation, increased vascular permeability, and monocyte chemotaxis. A direct effect on vessel permeability takes place through thrombininduced contraction of endothelial cells. ${ }^{41}$ This contraction results in the formation of intercellular gaps, and increased endothelial permeability to fluid and macromolecules. ${ }^{42}$

Adherence of polymorphonuclear leukocytes (PMN) to the vessel wall and their subsequent migration into tissues are important factors in the early stage of inflammation. Thrombin promotes these events in two ways. It is a chemoattractant for $\mathrm{PMN}^{43}$ and increases their adhesion to the endothelial surface. ${ }^{44} 45$ Thrombin also exhibits similar chemotactic and adhesion-stimulating properties for the monocytes seen later in the inflammatory response. ${ }^{464}$ It appears that thrombin can upregulate expression of the adhesive proteins $P$-selectin and intercellular adhesion molecule1 (ICAM-1) on the endothelial cell membrane, where the enzyme may act both alone and also synergistically with the cytokines IL-1 and tumour necrosis factor- $\alpha$ (TNF- $\alpha ;^{48}{ }^{49}$ ). $P$-selectin itself has recently been shown to play a major role during monocyte adhesion to the rheumatoid synovial vasculature. ${ }^{50}$

\section{MITOGENICITY AND HEALING}

The importance of platelet derived growth factors (PDGF), the fibroblast growth factors (FGF), and epidermal growth factor in proliferation and healing has been recognised for many years. Like these well-known mitogens, thrombin stimulates proliferation in fibroblastic and other cell types, with the response occurring at low concentrations of the enzyme. In vitro thrombin has been shown to be mitogenic for fibroblasts, lymphocytes, endothelial cells, vascular smooth muscle cells and monocytes. ${ }^{51-55}$ This mitogenesis can be stimulated by low levels of active thrombin, and we have observed thrombin-stimulated proliferation of murine 3T3 fibroblasts in the presence of only five NIH units of thrombin activity/ml culture medium. Fibroblasts are able to regulate such thrombin-induced proliferation by releasing the thrombin inhibitor PN-1 in a dose-dependent manner during thrombin stimulation. ${ }^{56}$

Thrombin also has an indirect effect on cellular growth. It causes the release of PDGF, ${ }^{57}$ and acts together with basic FGF in stimulating proliferation of vascular smooth muscle cells. ${ }^{58}$ Thrombin may therefore work with other growth factors in initiating the healing of inflamed tissues through proliferation and angiogenesis. Full dermal incisions in normal rats receiving a single topical application of thrombin showed accelerated healing and neovascularisation in the treated wounds. ${ }^{59}$ The mitogenic effects of thrombin may also be important in the cellular proliferation seen in RA (see below).

\section{The neural effects of thrombin}

Thrombin acts as a mitogen for astrocytes, ${ }^{60}$ non-neuronal supportive cells of the brain, but in contrast appears to inhibit the growth of neurons. In vitro it has been found to block neurite outgrowth from chick sympathetic ganglia and embryonic mouse spinal cord neurons. ${ }^{61}{ }^{62}$ Thrombin is also able to reverse neurite outgrowth from neuroblastoma cells that have been induced to extend neurites by serum removal. ${ }^{63}$ The location of prothrombin messenger RNA transcripts in rat and human cerebral cortex and cerebellum, as well as in neural cell lines, suggests that thrombin may be involved normally in development and function of the nervous system. ${ }^{64}$

The thrombin inhibitor PN-1 is abundant in and around the walls of human cerebral blood vessels. ${ }^{65}$ Here it may protect against the damaging effects of excess thrombin, which could leak from the vasculature into brain 
tissues as a consequence of injury or inflammation. It has been found that crushing rat peripheral nerves causes a seven-fold increase in the release of $\mathrm{PN}-1,{ }^{66}$ where maximum upregulation correlated with the appearance of macrophages in the tissue rather than the actul time of injury. IL-1, TNF- $\alpha$, and transforming growth factor- $\beta$ have also been shown to increase $\mathrm{PN}-1$ production by neural cells, the greatest effect being produced by IL1. ${ }^{67}$ However, a defensive mechanism based around PN-1 might be unable to maintain its integrity where there is widespread enzymatic inactivation of serpins, as is thought to take place during chronic inflammatory disease. The relevance of this observation to the proposed neural component of RA will be discussed in a later section.

\section{Mechanism of thrombin action}

During studies on the non-coagulative actions of thrombin it was found that mitogenesis and neurite retraction could not be reproduced when catalytically inactive forms of the enzyme were used. ${ }^{516368}$ Although modified thrombins and partial thrombin sequences bound to the thrombin receptor, they failed to elicit a cellular response. ${ }^{55} 6970$ This suggested that these actions of thrombin were dependent on its proteolytic activity, rather than being a simple binding interaction between enzyme and receptor as seen with many other ligands, for example, acetylcholine.

ACTIVATION OF THE THROMBIN RECEPTOR To clarify the mechanism of receptor activation, $\mathrm{Vu}$ et al cloned the human thrombin receptor, finding it to be a member of the seven transmembrane domain receptor family. ${ }^{71}$ These G-protein coupled receptors possess sequence similarities and share certain structural characteristics, particularly in the transmembrane regions. A large number of molecules work through such receptors, and differing activation mechanisms within the receptor family probably reflect the wide variety of ligands served. Thrombin, however, does not act by any of the previously described mechanisms. Instead the proposed model involves thrombin cleavage of an arginineserine bond within the receptor's extracellular $\mathrm{N}$-terminal region, creating a new $\mathrm{N}$-terminus which is itself the ligand for receptor activation. ${ }^{71}$ Current work is directed towards characterising the exact binding site of this 'tethered' ligand. It is likely that a similar or identical thrombin receptor is present on nonplatelet cells, since peptide agonists comprising the final 14 amino acids of the new $\mathrm{N}$-terminus are able to mimic the effects of thrombin on fibroblasts and other cell types in vitro. ${ }^{54} 557273$

\section{CELLULAR SIGNALIING PATHWAYS}

Three phospholipases are known to be stimulated after binding at the thrombin receptor. Activation of phospholipase $C^{72} 7475$ leads to hydrolysis of phosphatidyl inositol 4,5-bisphosphate $\left(\mathrm{PIP}_{2}\right)$ and release of its breakdown products, inositol trisphosphate $\left(\mathrm{IP}_{3}\right)$ and diacylglycerol (DAG). $\mathrm{IP}_{3}$ causes calcium to be liberated from intracellular stores, and this accounts for much of the rapid and sustained increase in cytosolic calcium seen after thrombin exposure of numerous cell types. ${ }^{73}$ 76-79 Calcium is able to bring about complex alterations in cytoskeletal components, including microtubule disassembly ${ }^{80}$ and activation of actin-depolymerising proteins. ${ }^{81}$ Raised calcium levels may therefore be linked with the morphological changes evoked by thrombin, such as endothelial cell contraction and neurite retraction.

The other product of $\mathrm{PIP}_{2}$ hydrolysis, DAG, is an activator of protein kinase C (PKC), and thrombin-stimulated cellular events can be blocked if PKC is first desensitised by treating the cells with phorbol esters. ${ }^{79} 82$ PKC phosphorylates cytoskeletal elements and so affects normal cytoskeletal function. For example, it directly stimulates endothelial cell contraction and thus increases vascular permeability. ${ }^{41}$ PKC also downregulates phospholipase $\mathrm{C}$, but is an upregulator of phospholipase $\mathrm{A}_{2}$ and $\mathrm{D} .{ }^{69}{ }^{83}$ Thrombinmediated activation of these enzymes causes the release of arachidonic acid, ${ }^{39}$ and conversion of phosphatidic acid into DAG which then potentiates PKC action.

\section{Pathological changes in the rheumatoid synovium}

CELLULAR PROLIFERATION

Progression of RA is marked by a dramatic increase in synovial thickness and the growth of pannus tissue, leading to disabling cartilage and bone erosions through the action of enzymes secreted by the fibroblast-like pannus cells. This synovial growth is thought to be caused by hyperplasia. However, mitoses are rarely found in the rheumatoid synovium, ${ }^{84}$ and use of a monoclonal antibody to mark proliferating cells showed few synoviocytes labelled positive in samples of RA synovia. ${ }^{85}$ These synovia were removed at joint replacement surgery from patients with longstanding disease, and thus it seems likely that proliferation occurs much earlier on in the disease process. Importantly, the joint erosions associated with synovial overgrowth have been found to develop within two years of RA onset. $^{86}$

\section{REDUCED SYNOVIAL INNERVATION}

Another potentially pathogenic change is seen in the innervation of the rheumatoid synovium. Normal synovium is well innervated by small diameter nerve fibres, found both perivascularly and as free fibres in the tissue, but these fibres are severely depleted in the synovial tissue of RA patients. In particular, although sympathetic innervation of deeper blood vessels matches that of normal synovium, there appear to be no sympathetic fibres around the more superficial vessels. ${ }^{87}$ 
Two main observations suggest that there is a neural influence in RA. First, the disease is characterised by its symmetry. Secondly, inflammation is precisely localised to the affected joints, and this is difficult to explain purely through the effects of circulating factors. Clinical data appear to confirm the involvement of the nervous system. ${ }^{88}$ For example, twelve patients previously paralysed by poliomyelitis showed almost total sparing of the paralysed limbs after the onset of RA. ${ }^{89}$

The 'axon reflex' theory suggests that small diameter nociceptive fibres are stimulated in inflammatory mediators in the inflamed joint. Impulses pass up through the spinal cord to higher centres, but are also propagated in reverse through the other branches of the nerves. ${ }^{90}$ Pro-inflammatory peptides are then thought to be released by the terminals of these fibres, exacerbating inflammation and causing further stimulation of the nociceptive fibres. ${ }^{88}$ This idea plausibly explains how inflammation can persist in RA whilst the innervation of the joint remains intact. Once the nerve fibres have been lost, however, such a mechanism could presumably no longer operate, and an inflammatory state must therefore be maintained by a different mechanism(s).

\section{A possible role for thrombin in the pathogenesis of RA}

Possibilities for the involvement of thrombin in RA are outlined in fig 2 . The microvascular network of the RA synovium has an increased permeability to plasma proteins, ${ }^{91}$ and morphological abnormalities of the microvasculature are a well described feature of the disease. ${ }^{92}$ Inflammatory changes in vessel permeability and bleeding from fragile capillaries in the hyperplastic synovium may allow plasma thrombin to enter the joint, with the presence of active thrombin being evidenced by synovial fibrin deposition. ${ }^{3}$ It is known in addition that fibrin monomers can reduce the susceptibility of thrombin to inactivation by AT-III. ${ }^{93}$

It appears that there is also thrombin generation by synovial macrophage-like cells, ${ }^{3}$ since macrophages are able to directly synthesise the components of the extrinsic coagulation cascade in situ, ${ }^{94}{ }^{95}$ and promote activation of all coagulation pathways at biologically meaningful rates. ${ }^{96}$ As thrombin is chemotactic for both PMN and macrophages this could form the basis for a proinflammatory feedback loop, in which there is recruitment of inflammatory cells to the joint,

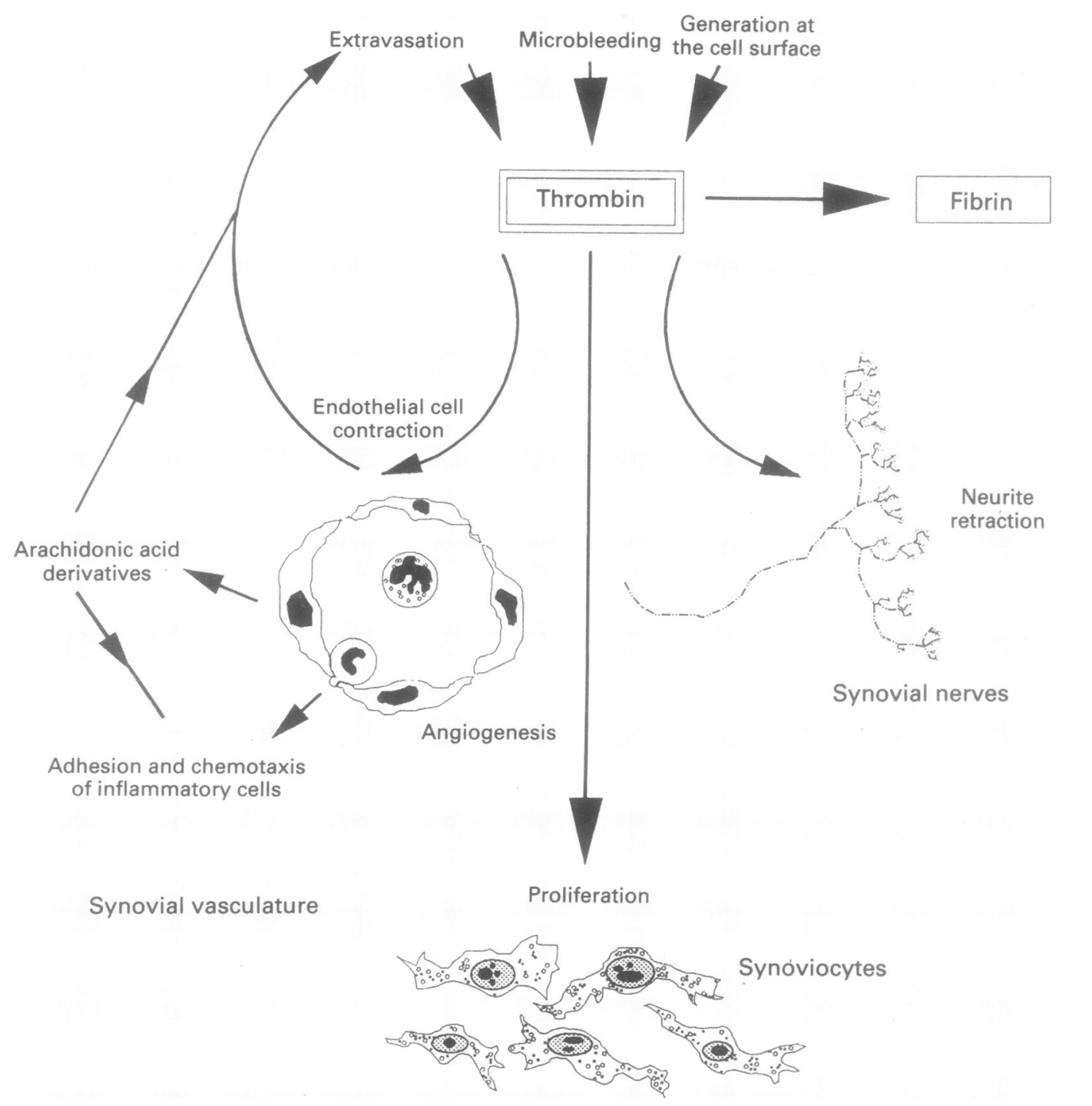

Figure 2 Outline of the proposed role of thrombin in $R A$. 
further production of thrombin in situ by these cells, and prolonged thrombin action due to damage of serpins by free radical and proteolytic mechanisms.

Through its mitogenic effects thrombin may elicit a cellular 'healing response' quite inappropriate to the chronic inflammatory condition of the rheumatoid joint. It is capable both of causing the proliferation of synoviocytes and stimulating angiogenesis. In support of this idea it is known that intraarticular bleeding has a detrimental effect on the synovial joint, as recurrent haemorrhage into the joints of non-RA sufferers can cause proliferative inflammatory synovitis such as that seen in haemophiliac patients. ${ }^{97}$ Injection of autologous blood into the rabbit knee also produces synovial proliferation, vascular dilatation, and the infiltration of inflammatory cells. ${ }^{98}$ We have recently shown that a single low dose of thrombin can induce a prolonged inflammatory response in the rat knee when given by intra-articular injection. ${ }^{99}$ In RA itself a significant correlation has previously been described beween the clinical severity of the disease and relevant histological features; capillary proliferation, synovial hyperplasia, and the presence of mononuclear cells. ${ }^{100}$ Thrombin receptor expression may be upregulated in RA, possibly increasing cellular responsiveness to the enzyme. Our preliminary studies using a monoclonal antibody to the human thrombin receptor indicate that there are large numbers of receptor-positive cells in rheumatoid synovia, but few cells staining positive in osteoarthritic synovia (Morris $\mathrm{R}$ et al, manuscript in preparation).

Finally, thrombin may be implicated in loss of nerves from the synovium. This could occur either by a direct effect of neuritogenesis, or because the stimulated synoviocyte growth is faster than the outgrowth of nerves through proliferating tissue. Under normal circumstances the peripheral nervous system defends itself against the harmful effects of thrombin generated during injury, by upregulating the production of $\mathrm{PN}-1$. In the chronically inflamed rheumatoid synovium it is likely that PN-1 would be inactivated by proteases, and hence this protective mechanism would no longer be effective.

\section{Conclusions}

Thrombin is a multifunctional enzyme involved in coagulation, inflammation, cell growth and neuronal development. Its effects may be influential in rheumatoid arthritis, both in maintaining a chronic inflammatory situation, and mediating pathological changes in synovial tissue such as synoviocyte proliferation and nerve loss. In addition, thrombin action in the rheumatoid joint is likely to be potentiated by local inactivation of endogenous inhibitors, through free radical and proteolytic mechanisms.

We thank the Arthritis and Rheumatism Council for Research and the Medical Research Council for financial support. We are also grateful to $\operatorname{Dr} S \mathrm{R}$ Stone for helpful discussions.
1 Tracy P B. Regulation of thrombin generation at cell surfaces. Semin Thromb Hemost 1988; 14: 227-33.

2 Nelken N A, Soifer S J, O'Keefe J, Vu T-K H, Charo I F, Coughlin $S \mathrm{R}$. Thrombin receptor expression in norma and atherosclerotic human arteries. $\mathcal{F}$ Clin Invest 1992; 90 1614-21.

3 Weinberg J B, Pippen A M M, Greenberg C S. Extravascular fibrin formation and dissolution in synovial tissue of patients with osteoarthritis and rheumatoid arthritis. Arthritis Rheum 1991; 34: 996-1005.

4 Zacharski L R, Brown F E, Memoli V A, et al. Pathways of coagulation activation in situ in rheumatoid synovial tissue. Clin Immunol Immunopathol 1992; 63: 155-62.

5 Esmon N, Owen W G, Esmon C T. Isolation of a membrane-bound cofactor for thrombin-catalyzed activation of protein C. F Biol Chem 1982; 257: 859-64.

6 McCachren S S, Diggs J, Weinberg J B, Dittman W A. Thrombomodulin expression by human blood monocytes and by human synovial tissue lining macrophages. Blood 1991; 78: 3128-32

7 Suzuki K, Stenflo J, Dahlback B, Teodorsson B. Inactivation of human coagulation factor $\mathrm{V}$ by activated protein C. F Biol Chem 1983; 258: 1914-20.

8 Conway E M, Nowakowski B. Biologically active thrombomodulin is synthesised by adherent synovial fluid cells and is elevated in synovial fluid of patients with rheumatoid arthritis. Blood 1993; 81: 726-33.

9 Carrell R W, Travis J. $\alpha_{1}$-antitrypsin and the serpins: variation and countervariation. TIBS 1985; 10: $20-4$.

10 Rosenberg R D, Damus $P S$. The purification and mechanism of action of human antithrombin-heparin mechanism of action of human antithromb

11 Olsen $S \mathrm{~T}$, Halvorsen $\mathrm{H}$ R, Bjork I. Quantitative characterization of the thrombin-heparin interaction. $\mathcal{F}$ Biol Chem 1991; 266: 6342-52.

12 Bar-Shavit R, Eldor A, Vlodavsky I. Binding of thrombin to the subendothelial extracellular matrix: protection and expression of functional properties. F Clin Invest 1989; 84: 1096-104.

13 Baker J B, Low D A, Simmer R L, Cunningham D D. Protease-nexin: a cellular component that links thrombin and plasminogen activator and mediates their binding to cells. Cell 1980; 21: 37-45.

14 Low D A, Baker J B, Koonce W C, Cunningham D D. Released protease-nexin regulates cellular binding, internalization and degradation of serine proteases. Proc Natl Acad Sci USA 1981; 78: 2340-4.

15 Savion N, Isaacs J D, Gosporadowicz D, Shuman M A. Internalization and degradation of thrombin and upregulation of thrombin-binding sites in corneal upregulation of thrombin-binding sites in

16 Wagner S L, Lau A L, Cunningham D D. Binding of protease nexin-1 to the fibroblast surface alters its target proteinase specificity. $\mathcal{F}$ Biol Chem 1989; 264: 611-5.

17 Tollefsen D M, Majerus D W, Blank M K. Heparin cofactor II. Purification and properties of a heparin-dependent inhibitor of thrombin in human plasma. $\mathcal{F}$ Biol Chem 1982; 257: 2162-9.

18 Griffith M J, Noyes C M, Tyndall J A, Church F C. Structural evidence for leucine at the reactive site of heparin cofactor II. Biochemistry 1985; 24: 6777-82.

19 Hatton M W C, Berry L R, Regoeczi E. Inhibition of thrombin by antithrombin III in the presence of certain glycosaminoglycans found in the mammalian aorta. Thromb Res 1978; 13: 655-70.

20 Church F C, Noyes C M, Griffith M J. Inhibition of chymotrypsin by heparin cofactor II. Proc Natl Acad Sci USA 1985; 82: 6431-4.

21 Farrell D H, Cunningham D D. Glycosaminoglycans on fibroblasts accelerate thrombin inhibition by protease nexin-1. Biochem f 1987; 245: 543-50.

22 Evans D L, McGrogan M, Scott R W, Carrell R W. Protease specificity and heparin binding and activation of recombinant protease nexin I. F Biol Chem 1991; 266: 22307-12.

23 Gebbink R K, Reynolds C H, Tollefsen D M, Mertens K, Pannekoek $H$. Specific glycosaminoglycans support the inhibition of thrombin by plasminogen activator inhibitor1. Biochemistry 1993; 32: 1675-80.

24 Bourin M-C, Lindahl U. Glycosaminoglycans and the regulation of blood coagulation. Biochem $\mathcal{f} 1993 ; 289$ : regulation

25 George P, Vissers M, Travis J, Winterbourn C, Carrell R. A genetically engineered mutant of $\alpha_{1}$ antitrypsin protects connective tissue from neutrophil damage and may be useful in lung disease. Lancet 1984; ii: 1426-8.

26 Docherty A J P, Murphy G. The tissue metalloproteinase family and the inhibitor TIMP: a study using CDNAs and recombinant proteins. Ann Rheum Dis 1990; 49: 469-79.

27 Winyard P G, Zhang Z, Chidwick K, Blake D R, Carrell $\mathrm{R} W$, Murphy $\mathrm{G}$. Proteolytic inactivation of human 279: $91-4$.

28 Mast A E, Enghild J J, Nagase H, Suzuki K, Pizzo S V, Salvesen $G$. Kinetics and physiologic relevance of the in inactivation of $\alpha_{1}$-proteinase inhibitor, $\alpha_{1}$-antichymotrypsin, and antithrombin III by matrix metalloproteinases-1 (tissue collagenase), $-2(72-\mathrm{kDa}$ gelatinase/ type IV collagenase), and -3 (stromelysin). 7 Biol Chem
1991; 266: 15810-6.

9 Zhang Z, Winyard P G, Chidwick $\mathrm{K}$, et al. Increased proteolytic cleavage of $\alpha_{1}$-antitrypsin ( $\alpha_{1}$-proteinase inhibitor) in knee-joint synovial fluid from patients with Chidwick K, Winyard P G, Zhang Z, Farrell A J, Blake D 
$R$. Inactivation of the elastase inhibitory capacity of $\alpha_{1}$-antitrypsin in fresh samples of synovial fluid from patients with rheumatoid arthritis. Ann Rheum Dis 1991, 50: $915-6$.

31 Carrell R W, Owen M C. Plakalbumin, $\alpha_{1}$-antitrypsin, antithrombin and the mechanism

32 Jordan R E, Nelson R M, Kilpatrick J, Newgren J O, Esmon $\mathrm{P}$ C, Fournel M A. Inactivation of human antithrombin by neutrophil elastase. $f$ Biol Chem 1989; 264: by neutrophil

33 Nick H, Hofsteenge J, Shaw E, Rovelli G, Monard D Functional sites of glia-derived nexin $(\mathrm{GDN})$ : importance of the site reacting with the protease. Biochemistry 1990 20: $2417-21$

34 Eidt J F, Allison P, Nobel S, et al. Thrombin is an important mediator of platelet aggregation in stenosed canin arteries with endothelial injury. 7 Clin Invest 1989; 84 18-27.

35 Esmon $\mathrm{C}$ T. The subunit structure of thrombin-activated factor V. F Biol Chem 1979; 254: 964-73.

36 Levine J D, Harlan J M, Harker L A, Joseph M L, Counts R B. Thrombin-mediated release of factor VIII antigen from human umbilical veins in culture. Blood 1982; 60 531-4.

37 Levin E G, Marzec U, Anderson J, Harker L A. Thrombin stimulates tissue plasminogen activator release from cultured human umbilical veins in culture. 7 Clin Inves 1984; 74: 1988-95.

38 Gelehrter T D, Sznycer-Laszuk R. Thrombin induction of plasminogen activator-inhibitor in cultured human endothelial cells. $\mathcal{F}$ Clin Invest 1986; 77: 165-9.

39 Weksler B B, Ley C W, Jaffe E A. Stimulation of endothelia cell $\mathrm{PGI}_{2}$ production by thrombin, trypsin, and ionophore A23187. F Clin Invest 1978; 62: 923-38.

40 Prescott S M, Zimmerman G A, McIntyre T M. Human endothelial cells in culture produce platelet activating factor (1-alkyl-2-acetyl-sn-glycero-3-phosphocholine) when stimulated with thrombin. Proc Natl Acad Sci USA 1984; 81: 3534-8.

41 Stasek J E, Garcia J G N. Role of protein kinase C in thrombin-mediated endothelial cell contraction and barrier dysfunction. Semin Thromb Hemost 1992; 18: $117-25$.

42 Laposta M, Dovnarsky D K, Shin H S. Thrombin-induced gap formation in confluent endothelial cell monolayers in vitro. Blood 1983; 62: 549-56.

43 Bizios R, Lai L, Fenton J W, Malik A B. Thrombin-induced chemotaxis and aggregation of neutrophils. $\mathcal{F}$ Cell Physio 1986; 128: 485-90.

44 Zimmerman G A, McIntyre T M. Thrombin stimulates the adhesion of neutrophils to human endothelial cells in vitro. F Clin Invest 1985; 76: 2235-46.

45 Bizios R, Lai L C, Cooper J A, Del Vecchio P J, Malik A B. Thrombin-induced adherence of neutrophils to cultured endothelial cell monolayers: increased endothelial adhesivity. 7 Cell Physiol 1988; 134: 275-80.

46 Bar-Shavit R, Kahn A, Wilner G D, Fenton J W. Monocyte chemotaxis: stimulation by specific exosite region in chemotaxis: stimulation by specific

47 Shankar R, de la Motte C A, DiCorleto P E. 3-deazaadenosine inhibits thrombin-stimulated plateletderived growth factor production and endothelialleukocyte adhesion molecule-1-mediated monocytic cell adhesion in human aortic endothelial cells. $\mathcal{F}$ Biol Chem 1992; 267: 9376-82

48 Sugama Y, Tiruppathi C, Janakidevi K, Andersen T T, Fenton J W, Malik A B. Thrombin-induced expression of endothelial P-selectin and intercellular adhesion molecule-1: a mechanism for stabilising neutrophil adhesion. f Cell Biol 1992; 119: 935-44.

49 Drake W T, Lopes N N, Fenton J W, Issekutz A C. Thrombin enhancement of interleukin-1 and tumor necrosis factor- $\alpha$ induced polymorphonuclear leukocyte migration. Lab Invest 1991; 67: 617-27.

50 Grober J S, Bowen B L, Ebling $\mathrm{H}$, et al. Monocyteendothelial adhesion in chronic rheumatoid arthritis. $\mathscr{f}$ Clin Invest 1993; 91: 2609-19.

51 Chen L B, Buchanan J M. Mitogenic activity of blood components I: thrombin and prothrombin. Proc Natl Acad Sci USA 1975; 72: 131-5.

52 Chen L B, Teng N N H, Buchanan J M. Mitogenicity of thrombin and surface alterations on mouse splenocytes. Exp Cell Res 1976; 101: 41-6.

53 Gosporadowicz D, Brown K D, Birdwell C R, Zetter B R. Control of proliferation of human

54 McNamara C A, Sarembock I J, Gimple L W, Fenton J W, Coughlin S R, Owens G K. Thrombin stimulates proliferation of cultured rat aortic smooth muscle cells by proliferation of cultured rat aortic smooth muscle cells by a prote.

55 Joseph S, MacDermot J. The N-terminal thrombin receptor fragment SFLLRN, but not catalytically inactive thrombin-derived agonists, activate U937 human monocytic cells:evidence for receptor hydrolysis in thrombin-dependent signalling. Biochem $\mathcal{f}_{1993 ; 290}$ thrombin.

56 Low D A, Scott R W, Baker J B, Cunningham D D. Cells regulate their mitogenic response to thrombin through secretion of protease nexin. Nature 1982; 298: 476-8.

57 Daniel T O, Gibbs V C, Milfay D F, Garavoy M R, Williams L T. Thrombin stimulates c-sis gene expression in microvascular cells. F Biol Chem 1986; 261: 9579-82.

58 Weiss R, Maduri M. The mitogenic effect of thrombin in vascular smooth muscle cells is largely due to basic fibroblast growth factor. $\mathcal{F}$ Biol Chem 1993; 268: 5724-7.

59 Carney D H, Mann R, Redlin W R, et al. Enhancement of incisional wound healing and neovascularisation in normal rats by thrombin and synthetic thrombin receptoractivating peptide. $\mathcal{F}$ Clin Invest 1992; 89: 1469-77.

60 Perraud F, Besnard F, Sensenbrenner M, Labourdette G. Thrombin is a potent mitogen for rat astroblasts but not for oligodendroblasts and neuroblasts in primary culture. Int f Dev Neurosci 1987; 5: 181-8.

61 Zurn A D, Nick H, Monard D. A glia-derived nexin promotes neurite outgrowth in cultured chick promotes neurite neurons. Dev Neurosci 1988; 10: 17-24.

62 Morris R, Owen A D, Bird M M. Thrombin blocks neurite outgrowth of embryonic mouse neurons in vitro. $\mathcal{F}$ Anat 1993 (in press).

63 Gurwitz D, Cunningham D D. Thrombin modulates and reverses neuroblastoma neurite outgrowth. Proc Natl Acad Sci USA 1988; 85: 3440-4

64 Dihanich $M$, Kaser $M$, Reinhard E, Cunningham D D, Monard D. Prothrombin mRNA is expressed by cells of the nervous system. Neuron 1991; 6: 575-81.

65 Choi B H, Suzuki M, Kim T, Wagner S L, Cunningham D D. Protease nexin-1: localization of the human brain suggests a protective role against extravasated serine suggests a protective role against extrav

66 Meier R, Spreyer P, Ortmann R, Harel A, Monard D. Induction of glia-derived nexin after lesion of a peripheral nerve. Nature 1989; 342: 548-50.

67 Vaughan $P$, Cunningham D. Regulation of protease nexin1 synthesis and secretion in cultured brain cells by injuryrelated factors. F Biol Chem 1993; 268: 3720-7.

68 Cavanaugh K P, Gurwitz D, Cunningham D D, Bradshaw R A. Reciprocal modulation of astrocyte stellation by thrombin and protease nexin-1. F Neurochem 1990; 54: 1735-43.

69 Garcia J G N, Fenton J W, Natarjan V. Thrombinstimulated phospholipase D activity in human endothelium: regulation by phospholipase $C$, protein kinase $C$, and cyclic adenosine $3^{\prime}, 5^{\prime}$-monophosphate. Blood 1992; 79: 2056-67.

70 Vouret-Craviari V, Obberghen-Schilling E, Rasmussen U B, Pavirani A, Lecocq J-P, Pouyssegur J. Synthetic alpha-
thrombin receptor peptides activate G protein-coupled signalling pathways but are unable to induce mitogenesis. Mol Cell Biol 1992; 3: 95-102.

$71 \mathrm{Vu} \mathrm{T}-\mathrm{K} \mathrm{H}$, Hung D T, Wheaton V I, Coughlin S R. Molecular cloning of a functional thrombin receptor reveals a novel proteolytic mechanism of receptor activation. Cell 1991; 64: 1057-68.

72 Hung D T, Vu T-K H, Nelken N A, Coughlin S R. Thrombin-induced events in non-platelet cells are mediated by the unique proteolytic mechanism established for the cloned platelet thrombin receptor. $\mathcal{F}$ Cell Biol 1992; 116: 827-32.

73 Jalink K, Moolenaar W H. Thrombin receptor activation causes rapid neural cell rounding and neurite retraction independent of classic second messengers. 7 Cell Biol 1992; 118: 411-19.

74 Brock T A, Capasso E A. Thrombin and histamine activate phospholipase $C$ in human endothelial cells via a phorbolester sensitive pathway. F Cell Physiol 1988; 136: 54-62.

75 Brass L F, Manning D R, Williams A G, Woolkalis M J, Poncz $M$. Receptor and $G$ protein-mediated responses to thrombin in HEL cells. 7 Biol Chem 1991; 266: 958-65.

76 Goligorsky M S, Denton D N, Laslo A, Lum H. Nature of thrombin-induced sustained increase in cytosolic calcium concentration in cultured endothelial cells. 7 Biol Chem 1989; 264: 16671-5.

77 Lapetina E G. The signal transduction induced by thrombin in human platelets. FEBS Lett 1990; 268: 400-4.

78 Brass L. Homologous desensitization of HEL cell thrombin receptors. F Biol Chem 1992; 267: 6044-50.

79 He C J, Peraldi M N, Adida C, et al. Thrombin signal transduction mechanisms in human glomerular epithelial cells. $\mathcal{F}$ Cell Physiol 1992; 150: 475-83.

80 Kumagai $\mathrm{H}$, Sakai H. The interaction between calmodulin and microtubule protein. Quantitative analysis of the binding between calmodulin and tubulin dimers. $f$ Biochem 1982; 93: 1259-336.

81 Pollard T D, Cooper J A, Actin and actin-binding proteins. A critical evaluation of mechanisms and functions. Ann Rev Biochem 1986; 55: 987-1035.

82 Herrick-Davies K, Camussi G, Bussolino F, Baglioni C. Modulation of neurite outgrowth in neuroblastoma cells by protein kinase $\mathrm{C}$ and platelet activating factor. $\mathcal{F} \mathrm{Biol}$ Chem 1991; 266: 18620-5.

83 McColl S, Hurst N, Cleland L. Modulation by phorbol myristate acetate of arachidonic acid release and leukotriene synthesis by human polymorphonuclear leukotriene synthesis by human polymorphonuclear
leukstes stimulated with A23187. Biochem Biophys Res Commun 1986; 141: 399-404

84 Coulton L A, Henderson B, Bitensky L, Chayen J. DNA synthesis in the human rheumatoid and non-rheumatoid synthesis in the human rheumatoid and non-rhe
synovial lining. Ann Rheum Dis 1980; 39: 241-7.

85 Lal P A, Mapp P I, Hall P A, Revell P A. Proliferative activity of cells in the synovium as demonstrated by a monoclonal antibody. Rheumatol Int 1987; 7: 183-6.

86 Brook A, Corbett $M$. Radiographic change in early rheumatoid disease. Ann Rheum Dis 1971; 36: 71-3.

87 Mapp P I, Kidd B L, Gibson S J, et al. Substance Pcalcitonin gene-related peptide- and $\mathrm{C}$-flanking peptide of neuropeptide Y-immunoreactive fibres are present in normal synovium but depleted in patients with rheumatoid arthritis. Neuroscience 1990; 37: 143-53. 
88 Kidd B L, Mapp P I, Blake D R, Gibson S J, Polak J M. Neurogenic influences in arthritis. Ann Rheum Dis 1990 49: 649-52.

89 Glick E N. Asymmetrical rheumatoid arthritis after poliomyelitis. BMF 1969; iii: 26-9.

90 Holzer P. Local effector functions of capsaicin-sensitive sensory nerve endings: involvement of tachykinins, calcitonin gene-related peptide and other neuropeptides. Neuroscience 1988; 24: 739-68.

91 Simkin P A, Pizzorno J E. Synovial permeability in rheumatoid arthritis. Arthritis Rheum 1979; 22: 689-96.

92 Stevens C R, Blake D R, Merry P, Revell P A, Levick J R A comparative study by morphometry of the microvasculature in normal and rheumatoid synovium. Arthritis Rheum 1991; 34: 1508-13.

93 Hogg P J, Jackson C M. Fibrin monomer protects thrombin from inactivation by heparin-antithrombin III implications for heparin efficiency. Proc Natl Acad Sci USA 1989; 86: 3619-23.

94 Lindahl U, Kolset K O, Bogwald J, Osterud B, Seljelid R. Studies, with a luminogenic peptide substrate, on blood coagulation factor X.Xa produced by mouse peritoneal macrophages. Biochem $\mathcal{F}$ 1982; 206: 231-7.

95 Lindahl U, Pejler G, Bogwald J, Seljelid R. A prothrombinase complex of mouse peritoneal macrophages. Arch Biochem Biophys 1989; 273: 180-8.

$96 \mathrm{McGee}$ M, Li L C, Hensler M. Functional assembly of intrinsic coagulation proteases on monocytes and platelets. $\mathcal{f}$ Exp Med 1992; 176: 27-35.

97 Mainardi C L, Levine P H, Werb Z, Harris E D. Proliferative synovitis in heamophilia. Arthritis Rheum 1978; 21: $137-44$.

98 Wolf C R, Mankin H J. The effect of experimental haemarthrosis on articular cartilage of rabbit knee joints. f Bone foint Surg 1965; 47A: 1203-10.

99 Morris R, Morris C J, Winyard P G, Martin J E. The proinflammatory action of intra-articular thrombin. Virchows Arch A Pathol Anat 1993 (in press).

100 Rooney M, Condell D, Quinlan W, et al. Analysis of the histologic variation of synovitis in rheumatoid arthritis. Arthritis Rheum 1988; 31: 956-63. 